\title{
Forord II
}

"... i empirisismen -.- opfattes ... begrepene ... som konstruksjoner, som bare har et subjektivt innhold.

... dette far ... den konsekvens at begrepet ikke bestemmes intensionalt, ikke sees $i$ sin historiske, motsetningsfylte utvikling. Enhver student $i$ et samfunnsvitenskapeligt fag, vet at dette forer til en odeleggelse av språket."

$$
\begin{aligned}
& \text { (Regi Th. Enerstuedt, Dialek- } \\
& \text { tikk og Samfunnsvitenskap, } \\
& \text { Ny Dag, 0slo, 1970, s. 65) }
\end{aligned}
$$

"Hela den empiristiska kunskapsprocessen vilar $\mathbf{i}$

själva verket $p a d$ den operation av subjektet som kallas abstraktion... Den empiristiska abstraktionen, som ur det givna verkliga objektet drar ur dets väsen, är en verklig abstraktion, som ger subjektet innehav av det verkliga väsendet... Verkligheten... består... av två verkliga väsenden, det rena väsendet och det orena, guldet och höljet ... det essentiella och det inessentiella..."

(A) thusser/Balibar, Att Läsa Kapitalet, $B O C$, Stockholm, 1970 , s. 43-44) 